\title{
Zadania notariatu łacińskiego w sferze obrotu nieruchomościami $z$ perspektywy systemu prawnego Stanów Zjednoczonych
}

DOI: http://dx.doi.org/10.12775/SIT.2013.006

W Stanach Zjednoczonych nie występuje instytucja notariusza $\mathrm{w}$ rozumieniu przyjętym $\mathrm{w}$ krajach civil law. Pomimo to przywołanie doświadczeń amerykańskich w badaniach nad notariatem łacińskim ${ }^{1}$ wydaje się uzasadnione. Przemawia za tym to, że - jak trafnie zauważają Konrad Zweigert i Hein Kötz - system prawny nie znosi pustki i powstrzymanie się od ingerencji publicznej w daną sferę stosunków społecznych tworzy przestrzeń dla substytucyjnej aktywności podmiotów prywatnych ${ }^{2}$. Warto zatem zbadać, czy prywatne instytucje powstałe w Stanach Zjednoczonych, które pełnią w tym kraju funkcje odpowiadające zadaniom stawianym nota-

\footnotetext{
${ }^{1}$ Pewne wątpliwości powstać mogą, jeśli chodzi o sposób rozumienia pojęć notariusza i notariusza łacińskiego. Tradycyjnie dla określenia notariuszy działających w krajach civil law używano pojęcia notariusze łacińscy. Od połowy lat osiemdziesiątych istnieje jednak tendencja do rezygnacji z członu „łaciński” dla podkreślenia tego, że anglosascy notary public w ogólne nie powinni być uznawani za notariuszy. $Z$ uwagi na prawno-porównawczy charakter opracowania i dla większej jasności wywodów tym artykule pojęcia notariusza i notariusza łacińskiego traktuję jako zwroty synonimiczne.

${ }^{2}$ Por. K. Zweigert, H. Kötz, An Introduction to Comparative Law, Oxford 2011 , s. 39.
} 
riuszom łacińskim w modelu civil law, są efektywne. Ewentualna pozytywna odpowiedź na to pytanie powinna skłaniać do daleko idącej wstrzemięźliwości w formułowaniu postulatów przekazywania notariuszom nowych, publicznych czynności, a być może nawet do rozpatrzenia celowości utrzymywania w systemie prawnym instytucji notariusza.

\section{Wykonywanie władzy publicznej przez notariusza łacińskiego i jego bezstronność}

Ambitną próbę określenia funkcji notariatu łacińskiego podjął Marek Kuryłowicz. Autor ten za trafne uznaje „określenie notariatu jako instytucji publicznej i notariusza jako osoby zaufania publicznego, wykonującego swój zawód w ramach systemu prawnego danego państwa, ale wyłączonego ze struktur administracyjnych i urzędowych organów państwowych. Do cech charakterystycznych, wspólnych notariatom europejskim tego modelu, zalicza się również rolę notariuszy jako gwarantów pewności prawa i bezkonfliktowości $\mathrm{w}$ obrocie prywatnoprawnym oraz rolę bezstronnego powiernika i doradcy prawnego" ${ }^{3}$. Kuryłowicz zwraca również uwagę na fakt, że notariusze nadają dokumentom charakter urzędowy ${ }^{4}$.

$Z$ punktu widzenia tematu artykułu na szczególną uwagę zasługują dwa elementy ustroju notariatu wyróżnione przez Kuryłowicza - powierzenie notariuszowi władzy publicznej oraz postawienie mu wymagania zachowania bezstronności.

W prawie polskim symbolicznym przejawem intensywnych powiązań między notariuszem a władzą publiczną jest to, że używa on pieczęci $z$ wizerunkiem orła (art. 8 Prawa o notariacie ${ }^{5}-$ dalej Pr. o not.). Rdzeń publicznego wymiaru działalności notariusza tworzy $\S 2$ Pr. o not., który stanowi, iż czynności notarialne, dokonane przez notariusza zgodnie $z$ prawem, mają charakter dokumentu

${ }^{3}$ M. Kuryłowicz, Notariat $w$ europejskiej kulturze prawnej, II Kongres notariuszy Rzeczypospolitej Polskiej. Referaty i opracowania, Poznań-Kluczbork 1999, s. 153, 154.

${ }^{4}$ Ibidem, s. 145.

5 Tekst jednolity Dz.U. z 2008 r. Nr 189, poz. 1158 ze zm. 
urzędowego. Zgodnie $\mathrm{z}$ art. $244 \S 1$ Kodeksu postępowania cywilnego $^{6}$ (dalej k.p.c.) dokumenty urzędowe, sporządzone w przepisanej formie przez powołane do tego organy władzy publicznej i inne organy państwowe w zakresie ich działania, stanowią dowód tego, co zostało w nich urzędowo zaświadczone.

Zakres władzy publicznej przekazanej notariuszom jest największy na gruncie art. 79 pkt 1 lit. a Pr. o not. oraz art. $777 \S 1$ pkt 4 i 5 k.p.c. Pierwszy $z$ tych przepisów stanowi, że notariusz sporządza akty poświadczenia dziedziczenia, które po zarejestrowaniu mają skutki prawomocnego postanowienia o stwierdzeniu nabycia spadku (art. 95 lit. j). Zgodnie $z$ art. $777 \S 1$ pkt 4 i 5 k.p.c. akty notarialne mogą być tytułami egzekucyjnymi, które po zaopatrzeniu w klauzule wykonalności stanowią podstawę egzekucji (art. 776 k.p.c.).

Immanentnemu powiązaniu notariusza $z$ władzą publiczną towarzyszy wymaganie zachowania formy aktu notarialnego dla najważniejszych czynności prawnych dotyczących nieruchomości. W myśl art. 158 Kodeksu cywilnego ${ }^{7}$ (dalej k.c.) umowa zobowiązująca do przeniesienia własności nieruchomości powinna być zawarta $\mathrm{w}$ formie aktu notarialnego. To samo dotyczy umowy przenoszącej własność, która zostaje zawarta w celu wykonania istniejącego uprzednio zobowiązania do przeniesienia własności nieruchomości.

Połączenie dwóch wskazanych wyżej rozwiązań - wymagania formy aktu notarialnego i wyposażenia notariusza w kompetencje do sporządzania dokumentów urzędowych $-\mathrm{z}$ punktu widzenia uczestników obrotu oznacza wyłączenie dopuszczalności dokonywania węzłowych czynności dotyczących nieruchomości bez interwencji publicznej. Antycypując dalsze rozważania, należy wskazać, że rozwiązanie to idzie wbrew regułom obowiązującym w systemie prawnym Stanów Zjednoczonych.

Obowiązek zachowania bezstronności przez notariusza uważa się za jeden $z$ węzłowych elementów określających jego status. Zgodnie $z$ art. 4 uchwały Komisji do spraw Międzynarodowej Współpracy

\footnotetext{
${ }^{6}$ Ustawa $z$ dnia 17 listopada 1964 r., Dz.U. Nr 43 poz. 296 ze zm.

7 Ustawa z dnia 23 kwietnia 1964 r., Dz.U. Nr 16 poz. 93 ze zm.
} 
Notarialnej (CCNI) i Stałej Rady Międzynarodowej Unii Notariatu „notariusza musi obowiązywać pełna bezstronność przy wykonywaniu jego czynności. Należy stworzyć nieprzekraczalne kryteria zabezpieczające taką bezstronność"8.

Normatywnym źródłem badanego obowiązku w prawie polskim jest art. $80 \S 2$ Pr. o not. Stanowi on, że przy dokonywaniu czynności notarialnych notariusz jest obowiązany czuwać nad należytym zabezpieczeniem praw i słusznych interesów stron oraz innych osób, dla których czynność ta może powodować skutki prawne. Należy podkreślić, że rozwiązanie przyjęte w tym przepisie odrywa zakres obowiązków notariusza od źródeł jego wynagrodzenia. Notariusz zobowiązany jest zapewnić ochronę praw oraz słusznych interesów wszystkich, dla których czynność może powodować skutki prawne, a wynagrodzenie uzyskuje od stron czynności. Są więc podmioty, których interesy notariusz musi zabezpieczyć pomimo że ze nie otrzymuje od nich wynagrodzenia.

Podniesienie zasady bezstronności notariusza do rangi jednego z elementów konstytuujących jego status i ścisłe związanie notariuszy $z$ władzą publiczną odrywają sposób funkcjonowania osób wykonujących wskazany zawód od mechanizmów wolnorynkowych. Specyfika ustroju notariatu została dostrzeżona w wyroku Trybunału Konstytucyjnego $\mathrm{z}$ dnia 10 grudnia 2003 r. W jego uzasadnieniu znajduje się stwierdzenie, że „pozycja notariusza różni się niewątpliwie od podmiotów świadczących typowe usługi prawnicze adwokatów, radców prawnych czy doradców podatkowych. Notariusz jest nie tylko osobą zaufania publicznego, ale pełni jednocześnie funkcje pomocnicze w stosunku do wymiaru sprawiedliwości”.

W tym kontekście należy też zwrócić uwagę na wyrok unijnego Trybunału Sprawiedliwości z dnia 24 maja 2011 r. w sprawie Komisja przeciwko Republice Federalnej Niemiec. Zgodnie $z$ nim „okoliczność, że czynności notarialne służą celom leżącym w interesie ogólnym - które w szczególności mają zagwarantować zgodność z prawem i pewność prawną czynności dokonywanych między jednostkami - stanowi nadrzędny wzgląd interesu ogólnego, który

8 Za A. Oleszko, Ustawowy obowiązek bezstronności notariusza, „Rejent” 2007, nr 10, s. 13. 
pozwala uzasadnić wynikające ze szczególnych cech działalności notarialnej ewentualne ograniczenia w odniesieniu do art. $43 \mathrm{WE}$ (obecnego art. 49 TFUE - MKK), takie jak ramy, którym podlegają notariusze $\mathrm{w}$ toku stosowanych do nich procedur naboru, ograniczenie ich liczby oraz kompetencji terytorialnych lub także ich reżim wynagradzania, niezawisłości, zakazu łączenia stanowisk i nieusuwalności, o ile ograniczenia te pozwalają osiągnąć wspomniane cele i są ku temu niezbędne"9.

\section{Zarys systemu obrotu nieruchomościami w Stanach Zjednoczonych}

Najważniejszym obszarem działalności notariuszy jest obrót nieruchomościami. Jego reguły, obowiązujące w Stanach Zjednoczonych, nie są dobrze znane w Polsce. Podjęcie próby zestawienia, właściwej państwom civil law, instytucji notariusza i adekwatnych unormowań amerykańskich powinno być poprzedzone w związku z tym, przynajmniej skrótowym, przedstawieniem zasad dokonywania czynności prawnych dotyczących nieruchomości w prawie Stanów Zjednoczonych.

\subsection{Umowy dotyczące nieruchomości}

Na treść reguł obrotu nieruchomościami w Stanach Zjednoczonych silny wpływ wywarła, właściwa kulturze prawnej tego państwa, niechęć wobec interwencji publicznej w prywatne stosunki prawne ${ }^{10}$. We wszystkich stanach podmioty prywatne mają prawo

9 C-54/08.

${ }^{10} \mathrm{~W}$ tym miejscu należy poczynić pewne uwagi terminologiczne. W języku angielskim równolegle funkcjonują dwa bliskoznaczne zwroty real property oraz conveyancing. W doktrynie wskazuje się, że pierwszy z nich ma charakter statyczny i dotyczy zasadniczo praw właściciela nieruchomości. Zwrot conveyancing znajduje natomiast zastosowanie do powstawania i przenoszenia praw rzeczowych - por. C. Harpum, S. Bridge, M. Dixon, The Law of Real Property, London 2012, s. 2. 
do dokonania czynności prawnych każdego rodzaju bez udziału profesjonalistów i urzędników publicznych, innych niż pracownicy rejestrów ("it is probably fair to say that in every American state, private parties have the power to conclude, document and effectuate their own legal transactions and private law agreements of every kind without the intervention of any professional or public official, other than recording officials serving in ministerial capacities"11).

W Stanach Zjednoczonych istnieją jednak pewne ograniczenia swobody kontraktowej stron w zakresie obrotu nieruchomościami. Tak w szczególności, wbrew tradycji common law, w prawie amerykańskim dla czynności prawnych dotyczących nieruchomości wymagane jest zachowanie formy pisemnej. W większości stanów stosowne dokumenty dotyczące przeniesienia własności nieruchomości gruntowych muszą zostać przedłożone do rejestracji niższym funkcjonariuszom publicznym - zazwyczaj notary public lub sędziom pokoju. Peter L. Murray i Rolf Stürner wskazują jednak, że znaczenie tych rejestrów jest bardzo ograniczone. Przy dokonywaniu wpisów nie bada się ani treści czynności, ani ,jakości” przenoszonych praw ("It says nothing of the content of the deed or of the quality of the title conveyed" ${ }^{12}$ ).

Zwraca się również uwagę, że ograniczenia dotyczące obrotu nieruchomościami wynikają $z$ orzecznictwa. W piśmiennictwie podkreśla się jednak, że interwencja sądów ma charakter następczy, a podejmowanie prób formułowania generalnych reguł $\mathrm{w}$ drodze uogólnienia jednostkowych rozstrzygnięć nastręcza poważnych trudności ${ }^{13}$. Podnosi się też, że uczestników obrotu w pewnym zakresie dyscyplinują wymagania rynku. Dotyczy to w szczególności tzw. wtórnego rynku hipotecznego ("real estate mortgages are sold on a secondary market"14).

Rozwój wtórnego rynku kredytów hipotecznych (secondary market for home mortgages) doprowadził jednak również do tego, że w Stanach Zjednoczonych regułą stała się standaryzacja umów

${ }^{11}$ P.L. Murray, R. Stürner, The Civil Law Notary - Neutral Lawyer for the Situation, Münich 2010, s. 104.

12 Ibidem, s. 106.

13 Ibidem, s. 108.

14 Ibidem, s. 109. 
i zabezpieczanie ich przy pomocy ubezpieczeń (title insurance). Treść kontraktów jest kształtowana tak, by kredyty były jak najbardziej atrakcyjne na rynku wtórnym, co odbywa się często ze szkodą dla ich przejrzystości. Efektem takiego stanu rzeczy jest to, że - jak stwierdza Murray - wielu Amerykanów dokonuje najważniejszych $\mathrm{w}$ życiu transakcji, nie zdając sobie sprawy $z$ tego, co robi ${ }^{15}$.

\subsection{System rejestrowy}

Mankamentem obowiązujących w Stanach Zjednoczonych reguł obrotu nieruchomościami jest brak powszechnego, efektywnego systemu rejestrowego. W doktrynie wskazuje się, że stan większości nieruchomości gruntowych nie jest ujawniany w żadnym rejestrze ("the great bulk of land in the United States is not registered"16).

Pod koniec XIX wieku 23 amerykańskie stany wprowadziły system rejestracyjny Torresa, który powstał w Australii. Obecnie jest on stosowany w Minnesocie, Massachusetts, Colorado, Georgii, Nowym Jorku, Północnej Karolinie, Ohio, Washingtonie i na Hawajach. Przedmiotowy system jest najbardziej popularny w Massachusetts, w którym rejestrowanych jest do 30\% nieruchomości gruntowych. $\mathrm{W}$ pozostałych wskazanych stanach rejestruje się nie więcej niż $10 \%$ nieruchomości gruntowych ${ }^{17}$.

Najważniejszą przyczyną niewielkiej popularności rejestrów nieruchomości w Stanach Zjednoczonych jest to, że korzystanie $z$ nich w żadnym ze stanów nie jest obligatoryjne, a właściciel może doprowadzić do wpisania swojej nieruchomości w rejestrze jedynie w kosztownym, sądowym postępowaniu. Pomimo tego, iż rejestracja przynosi wymierne korzyści kolejnym właścicielom, osoba która zdecydowała się na przeprowadzenie omawianej procedury i poniosła jej koszty, nie korzysta bezpośrednio $z$ jej dobrodziejstw ${ }^{18}$.

15 Por. P.L. Murray, French Notaries and the American Mortgage Crisis, dostępne na http://mainelaw.maine.edu/academics/pdf/2010_franco_ amer_275.pdf, (dostęp: 13.06. 2013), s. 282.

${ }^{16}$ Por. P.L. Murray, R. Stűrner, op.cit., s. 128.

17 Ibidem.

18 Ibidem. 
Murray i Stürner stwierdzają, że niechęć właścicieli do ponoszenia kosztów rejestracji, z której korzystać będą głównie kolejni nabywcy, jest zrozumiała.

Zweigert i Kötz zauważają, że na niektórych obszarach funkcje substytucyjne wobec kontynentalnych rejestrów nieruchomości w Stanach Zjednoczonych pełnią Title Insurance Companies. Są to prywatne instytucje ubezpieczeniowe, które zapewniają swoim klientom ochronę przed szkodami, jakie mogą wyniknąć $z$ roszczeń osób trzecich ("guarantee the insured against any loss he may suffer should a third person's rights diminish the value of his property"19). Towarzystwa te prowadzą własne rejestry i ubezpieczają tylko czynności prawne, których bezpieczeństwo uwiarygodniają zgromadzone przez nie dane. Wiele spośród Title Insurance Companies działa od przeszło wieku i ma praktycznie monopol na lokalnym rynku, co prowadzi do tego, że prowadzone przez nie rejestry są na pewnych obszarach praktycznie kompletne (virtually complete) ${ }^{20}$.

\section{Rola prawników w obrocie nieruchomościami w systemie prawnym Stanów Zjednoczonych}

Zawód prawnika ma w Stanach Zjednoczonych charakter jednolity, a wykonujące go osoby muszą posiadać stosowną licencję. Warto nadmienić, że odpłatne świadczenie porad prawnych przez osoby nie posiadające licencji jest penalizowane ${ }^{21}$.

Teoretycznie każdy zainteresowany może zapewnić sobie obsługę prawną przy czynnościach obrotu nieruchomościami, zatrudniając prawnika, który będzie reprezentować tylko jego interesy. Murray stwierdza jednak, że w systemie Stanów Zjednoczonych prawnik sprzedającego chroni jedynie jego interesy. Analogicznie wygląda zakres obowiązków profesjonalistów zaangażowanych przez kupującego i bank ${ }^{22}$. Zatrudnienie kilku prawników do obsługi jednej

\footnotetext{
${ }^{19}$ K. Zweigert, H. Kötz, op.cit., s. 39.

${ }^{20}$ Ibidem.

${ }^{21}$ Por. P.L. Murray, R. Stűrner, op.cit., s. 109, 111.

22 P.L. Murray, op.cit., s. 281.
} 
transakcji jest kosztowne i rodzi wiele komplikacji, co prowadzi do tego, że w praktyce amerykański system obrotu nieruchomościami funkcjonuje zazwyczaj inaczej niż przedstawiony model.

W ostatnich latach regułą stało się to, że w większości umów obsługę prawną zapewniają podmioty - title companies ${ }^{23}$ lub prawnicy - zaangażowane przez instytucje finansowe i odpowiadające tylko wobec nich. Sprzedający i kupujący są natomiast zazwyczaj pozbawieni reprezentacji prawnej ("much of the work conveyancing and documenting of real estate transactions had come to be performed by title companies and lawyers who are chosen by, and represent the interests of, financing banks or mortgage companies. Buyer and seller typically go unrepresented") ${ }^{24}$.

W tym miejscu warto zwrócić uwagę na stosunek amerykańskiego systemu prawnego do zasady lojalności prawnika wobec klienta. Dobrze obrazuje go stwierdzenie lorda Broughama wyrażone w sprawie The Queen ${ }^{25}$. Zgodnie $z$ nim przedstawiciele wskazanej grupy zawodowej, wypełniając swe obowiązki, „znają tylko jedną osobę na świecie, a tą osobą jest klient”. Co więcej, zgodnie z przedstawianym stanowiskiem, „pierwszym i jedynym obowiązkiem” prawnika jest bronić klientów wszelkimi dostępnymi środkami, bez względu na interesy innych osób ("an advocate, in the discharge of his duty, knows but one person in all the world, and that person is his client. To save that client by all means and expedients, and at all hazards and costs to other persons [...] is his first and only duty; and in performing this duty he must not regard the alarm, the torments, the destruction which he may bring upon others" $\left.{ }^{26}\right)$. Geoffrey C. Hazard stwierdza, że cytowana wypowiedź, z jej kategorycznymi stwierdzeniami - „pierwszym i jedynym obowiązkiem”, „nie zna nikogo innego na świecie" - stała się credo dla wielu przedstawicieli

${ }^{23} \mathrm{~W}$ większości stanów możliwe jest powierzenie obsługi prawnej czynności obrotu nieruchomościami title companies, które najczęściej są kontrolowane przez prawników - por. P.L. Murray, R. Stürner, op.cit., s. 112-113.

24 Por. P.L. Murray, op.cit., s. 281.

${ }^{25} 2$ Trial of Queen Caroline 3 (1821) - cyt. za: P.L. Murray, R. Stürner, op.cit., s. 110.

${ }^{26}$ Ibidem. 
palestry $^{27}$. Autor ten wskazuje, że zgodnie $z$ tą linią rozumowania nałożenie na prawnika obowiązków wobec kogokolwiek innego niż jego klient nieuchronnie prowadzi do ograniczenia jego obowiązków wobec klienta, czego skutkiem jest powstanie konfliktów interesów. Za właściwe uznaje się więc podporządkowanie niemal wszystkich obowiązków prawnika interesowi jego klienta. Przyjmuje się również, że wyjątki od tej zasady powinny być rzadkie i dotyczyć jedynie „ekstremalnych" przypadków, takich jak oszustwo ("the scope of lawyer's duties, according to the conventional advocacy model, is wholly oriented to the client, with a few exceptions dealing with extreme cases such as fraud"28).

Podmioty profesjonalne obsługujące czynności obrotu nieruchomościami (title companies, prawnicy) nie mają obowiązku udzielania porad i dbania o ochronę interesów nikogo innego niż ich klienci. Jeżeli czynność okaże się wadliwa w sposób niegodzący w interesy instytucji finansowych, lecz dotkliwy dla sprzedającego lub kupującego, nie można zazwyczaj stawiać żadnych zarzutów prawnikom, czy też title companies.

Należy również wskazać, że w prawie amerykańskim rola notary public jest marginalna, a osób pełniących tę funkcję, poza warstwą semantyczną, niemal nic nie łączy z notariuszami działającymi w ramach modelu łacińskiego ${ }^{29}$. Nawet w Luizjanie, a więc w stanie, na którego system prawa cywilnego duży wpływ wywarło prawo francuskie, a zwłaszcza tzw. kodeks Napoleona, notary public nie mogą

27 G.C. Hazard, Lawyer for the Situation, "Valparaiso University Law Review" 2004, vol. 39, nr 2, s. 378-379. Autor ten zwraca uwagę, że amerykańscy prawnicy powołują się na stanowisko lorda Broughama szczególnie chętnie w przypadkach, gdy kierowane są wobec nich zarzuty wyrządzenia szkody podmiotom innym niż ich klienci. Dla zilustrowania tego zagadnienia przywołuje on sprawę Schatz v. Rosenberg, 943 F.2d 485 (4th Cir. 1991), w której za dopuszczalne uznano świadome przekazanie przez prawnika fałszywego oświadczenia finansowego ("which countenanced a lawyer`s transmittal of a financial statement that, he knew to be fals").

${ }^{28}$ Ibidem, s. 379.

${ }^{29}$ Por. N.P. Ready, Brookes's Notary, „Padstow” 2009, s. 42, 43; K. Zweigert, H. Kötz, op.cit., s. 368. 
być porównywalni $z$ notariuszami łacińskimi. Należy podkreślić, że nie wymaga się od nich nawet wykształcenia prawniczego ${ }^{30}$.

\section{Propozycja wprowadzenia do systemu prawa Stanów Zjednoczonych instytucji notariusza}

Warto zwrócić uwagę na fakt, że w doktrynie pojawia się postulat wprowadzenia do systemu prawnego Stanów Zjednoczonych instytucji notariusza. Propozycje idące w tym kierunku stały się nośne zwłaszcza po kryzysie finansowym, który rozpoczął się od załamania na amerykańskim rynku nieruchomości.

Szczególnie interesujące jest zwłaszcza stanowisko wyrażone przez Roberta J. Shillera, który jest uznawany za jednego ze 100 najbardziej wpływowych ekonomistów świata ${ }^{31}$. Badając źródła kryzysu finansowego lat 2007-2010, teoretyk ten wskazał, że doprowadziło do niego pęknięcie bańki spekulacyjnej, która rozrastała się na amerykańskim rynku nieruchomości od końca lat dziewięćdziesiątych $\mathrm{XX}$ wieku ${ }^{32}$. Amerykańska opinia publiczna długo była przekonana, że nabywanie nieruchomości jest niezwykle opłacalne i bezpieczne. Nadmierny entuzjazm wobec inwestowania we wskazane dobra wspierały też władze publiczne, które upowszechnienie własności nieruchomości uznawały za istotny cel polityki państwa. Shiller twierdzi, że rozrost bańki spekulacyjnej

${ }^{30} \mathrm{~W}$ ostatnich latach pojawiły się propozycje wprowadzenia notariuszy typu łacińskiego do prawa Florydy. Ma to ścisły związek $z$ faktem, iż wielu mieszkańców tego stanu pochodzi z państw Ameryki Południowej i Środkowej, w których funkcjonuje notariat typu łacińskiego - por. P.L. Murray, R. Stűrner, op.cit., s. 115.

${ }^{31}$ R.J. Shiller pełnił m.in. funkcje przewodniczącym Wschodniego Towarzystwa Ekonomicznego (Eastern Economic Association) oraz wiceprzewodniczącego Amerykańskiego Stowarzyszenia Ekonomicznego (American Economic Association), a naukowo związany jest z Yale University i Yale School of Management - cyt. za: http://en.wikipedia.org/wiki/Robert_J._Shiller.

${ }^{32}$ R.J. Shiller, The Subprime Solution: How Today's Global Financial Crisis Happened, and What to Do about It, Princeton 2008, s. 33; por. recenzja M.K. Kolasińskiego, „Rejent” 2011, nr 10. 
stymulowała również nieodpowiedzialność kredytodawców i ich pracowników oraz agresywna postawa kredytobiorców ${ }^{33}$. Gdy w połowie 2006 roku spekulacyjne napędzana podaż nieruchomości - głównie domów - osiągnęła rozmiar, którego nie mógł zrównoważyć popyt, doszło do gwałtownego spadku cen i powstania niepokoju na rynku. W tej sytuacji podniesiono stopy kredytów hipotecznych, co jeszcze bardziej ograniczyło popyt. W kolejnych miesiącach coraz większa liczba kredytobiorców zalegała ze spłatą kolejnych rat, a wysokość zobowiązań zaciągniętych na zakup nieruchomości przed kryzysem w wielu przypadkach zaczęła przewyższać ich ówczesną rynkową wartość. Niewypłacalność kredytobiorców przyniosła duże straty sektorowi finansowemu, a kryzys rozlał się na inne sfery gospodarki Stanów Zjednoczonych, a następnie dotknął niemal wszystkich krajów.

Analiza źródeł kryzysu prowadzi Shillera do sformułowania propozycji zreformowania amerykańskiego systemu obrotu nieruchomościami. Zdaniem wskazanego autora, uzasadnione byłoby m.in. przeniesienie na grunt prawa Stanów Zjednoczonych instytucji notariusza $^{34}$. Shiller wskazuje, że notariusze umożliwiają wszystkim uczestnikom obrotu dostęp do rzetelnej i bezstronnej porady prawnej. W jego wywodach można odnaleźć wyraźną aprobatę dla uzupełnienia systemu prawnego Stanów Zjednoczonych o instytucję bezstronnego prawnika, który wykonywałby uprawnienia przyznane mu przez władze publiczne. Zdaniem powołanego ekonomisty, rozwiązanie takie utrudniłoby kredytodawcom dokonywanie nadużyć, polegających na pozbawianiu kontrahentów adekwatnej informacji o ryzyku, na które się narażają ("The participation of such a government-appointed figure in mortgage lending process would make it more difficult for unscrupulous mortgage lenders to steer their clients toward sympathetic lawyers, who could not adequatly warn the clients of the dangers they could be fading"35).

U ujęciu prezentowanym przez Shillera wprowadzenie do systemu prawnego Stanów Zjednoczonych instytucji notariusza łaciń-

\footnotetext{
33 Por. R.J. Shiller, op.cit., s. 6.

${ }^{34}$ Ibidem, s. 134.

35 Ibidem.
} 
skiego byłoby krokiem zmierzającym do przywrócenia zaufania na rynku. Należy podkreślić, że właśnie brak zaufania w obrocie jest uznawany przez tego uczonego za główną przyczynę powstawania baniek spekulacyjnych, których nieuchronne pękanie wywołuje kryzysy ("The key to long-term economic sukces is rightly placed confidence in markets"36).

Ze stanowiskiem Shillera koresponduje pogląd Rolfa Kniepera, który twierdzi, że podjęciu niewłaściwych decyzji inwestycyjnych przez nabywców nieruchomości mogłyby przynajmniej w pewnym zakresie zapobiec udzielane ex ante porady oraz interwencja publiczna w mechanizmy obrotu ${ }^{37}$.

W zbliżonym duchu utrzymane są wywody Murray i Stürner. Autorzy ci ubolewają, że mimo raczej oczywistych korzyści, jakie mogłoby przynieść wprowadzenie instytucji notariusza typu łacińskiego do porządku prawnego Stanów Zjednoczonych, przedstawiciele tego zawodu są przez amerykańskich prawników często postrzegani jako „komiczna figura” $z$ włoskiej opery. Takiemu obrazowi notariuszy towarzyszy bardzo mała liczba anglojęzycznych publikacji dotyczących notariatu ${ }^{38}$.

Murray i Stürner stwierdzają, że to, czy brak dostępu do bezstronnej porady prawnej przyczynił się do powstania bańki spekulacyjnej, której pęknięcie doprowadziło do załamania amerykańskiego rynku nieruchomości w 2007 roku, stanowi przedmiot dyskusji w doktrynie. Wskazują oni, że część piśmiennictwa uważa, że gdyby nabywcy nieruchomości mogli uzyskać poradę od bezstronnego notariusza, zastanowiliby się dwukrotnie przed dokonaniem pochopnych transakcji. Murray i Stürner zwracają jednak uwagę na fakt, że kredytodawcy tak bardzo stymulowali popyt na swoje usługi, że jest mało prawdopodobne, by wielu kredytobiorców od zaciągania zobowiązań mogły odwieść nawet niezależne porady prawne udzielone przez bezstronnego prawnika ${ }^{39}$.

${ }^{36}$ Ibidem, s. 171.

37 R. Knieper, Economic Analysis of Notarial Law and Practice, "Beck" 2009, s. 116 (30) - cyt. za: P.L. Murray, R. Stürner, op.cit., s. 121.

38 Por. P.L. Murray, R. Stürner, op.cit., s. 6.

39 Ibidem, s. 120. 
Precyzując swoje wywody, Murray argumentuje, że prawdopodobne jest, iż uczestnictwo notariusza w obrocie nieruchomościami ograniczyłoby szczególnie daleko idące nadużycia kredytodawców z dwóch powodów. Po pierwsze, notariusze wyjaśnialiby nabywcom osobiście treść umów, a zwłaszcza ryzyko wiążące się z ich zawarciem. Po drugie, udział notariuszy w obrocie doprowadziłby do tego, że umowy byłyby redagowane w bardziej przejrzysty sposób, a amerykańska praktyka na tej płaszczyźnie pozostawia wiele do życzenia ${ }^{40}$.

Murray i Stürner wyrażają śmiałą tezę, że przynajmniej w sferze obrotu nieruchomościami można sobie wyobrazić funkcjonowanie amerykańskiej postaci neutralnego prawnika, który działałby podobnie do notariusza łacińskiego ("it may be possibile to conceive o fan American form of neutral legal practitioner similar to a civil law notary, at least in the context of real estate transactions" ${ }^{41}$ ). Autorzy ci podkreślają jednocześnie, że rozwój takiej instytucji musiałby opierać się na obecnych uwarunkowaniach polityczno-ekonomicznych, a nie na spuściźnie prawa rzymskiego.

\section{Podsumowanie}

Zgodnie $\mathrm{z}$ prawidłowościami zaobserwowanymi przez Zweigerta i Kötza, w braku aktywności publicznej w danej sferze, rynek dąży do stworzenia instytucji prywatnych wobec niej substytucyjnej ${ }^{42}$.

Rozwiązania wytworzone w modelu amerykańskim, które mają pełnić funkcje analogiczne do zadań stawianych notariatowi łacińskiemu, w praktyce nie działają w sposób satysfakcjonujący. Za trafny można również uznać ogólniejszy pogląd, że rynek nie jest w stanie, bez interwencji publicznej, dostarczyć uczestnikom obrotu nieruchomościami efektywnego substytutu notariatu łacińskiego.

\footnotetext{
${ }^{40}$ Por. P.L. Murray, op.cit., s. 283.

${ }^{41}$ Por. P.L. Murray, R. Stürner, op.cit., s. 197.

${ }^{42}$ Por. K. Zweigert, H. Kötz, op.cit., s. 39.
} 


\section{SUMMARY}

Functions of a Civil Law Notary in real estate transactions from the point of view of the United States Legal System

In the United States legal system there is no such thing as a notary within the meaning accepted in the civil law culture. Nevertheless, taking account of the U.S. experience in research upon Latin notary is not pointless.

The legal system abhors a vacuum and refraining by public authorities from undertaking activity on a particular area creates some room for substitute private action.

It is worth examining if the private law institutions developed in the U.S. which fulfill the functions reserved for notaries in civil law system are sufficiently efficient.

Keywords: Notary, Real Estate. 
